\title{
SEROPREVALENCE OF HEPATITIS-C VIRUS IN BLOOD DONORS AND HIGH RISK INDIVIDUALS
}

Nirmala Poddar, Priya Ranjan Lenka, Nirupama Chayani, Sunil Mohanty, Bandana Mallick, Dipti Pattnaik

1. Assistant Professor, Department of Microbiology, KIMS. Odisha, India.

2. Tutor, Department of Microbiology, KIMS. Odisha, India.

3. Professor \& HOD, Department of Microbiology, S.C.B. MCH. Odisha, India.

4. Professor \& HOD, Department of Microbiology, KIMS. Odisha, India.

5. Associate Professor, Department of Microbiology, KIMS. Odisha, India.

6. Professor, Department of Microbiology, KIMS. Odisha, India.

\section{CORRESPONDING AUTHOR}

Dr. N. Poddar,

Department of Microbiology,

Kalinga Institute of Medical Sciences,

Odisha, India.

E-mail: drnirmalapoddar@gmail.com

Ph: 00919437017785

ABSTRACT: Hepatitis C virus (HCV) continues to be a major disease burden affecting about 200 million people in world. Using blood donors as a prevalence source may underestimate the real prevalence of the virus because the donors are highly selected population. Presently more evidences support intravenous drug use as leading risk factor for the spread of virus. OBJECTIVES: The study aims at finding out the seroprevelance of Hepatitis $C$ virus in high risk individuals as well as healthy blood donors. SETTINGS AND DESIGN: The study group comprise of 350 subjects which included 150 healthy voluntary donors as control group and 200 subjects taken from different high risk population like intravenous drug abuser (50), patients on long term haemodialysis (40), patients with chronic liver disease (50), HIV positive cases (30), health care workers (30). STATISTICAL ANALYSIS USED: Percentage. RESULTS: Seropositivity for anti HCV antibody was found to be $12 \%$ (24/200) among high risk population and $0.66 \%(1 / 150)$ in healthy voluntary blood donors. Among different high risk groups, maximum prevalence rate $28 \%(14 / 50)$ was found in I.V drug abusers. Fifty percent $(7 / 14)$ of the seropositive parenteral drug abusers were male in the age group of 21-30 years followed by $35.7 \%(5 / 14)$ in $31-40$ years of age group. Only one female $(7.14 \%)$ between $21-30$ years was found to be sero-reactive for antiHCV antibody. In HIV co-infected cases $13.33 \%(4 / 30)$ were seropositive for antiHCV antibody. In chronic liver disease (two hepatocellular carcinoma, one cirrhosis and one chronic hepatitis) and long standing haemodialysis, the prevalence rate for anti HCV was found to be $8 \%(4 / 50)$ and 5\% (2/40) respectively. None of the health workers $(0 / 30)$ found to be sero-reactive for antiHCV antibody. CONCLUSIONS: HCV poses a serious worldwide health problem affecting people from all walks of life in every country. In the present study $12 \%$ and $0.66 \% \mathrm{HCV}$ prevalence was noticed in high risk group and healthy blood donors respectively. Among high risk group maximum prevalence (58.33\%) was found in IV drug abusers. Prevention should target the reduction of virus transmission by health education, risk reduction counseling and thorough HCV screening following the suggestion of CDC, Atlanta, USA.

KEY WORDS: Hepatitis C virus, Intravenous drug use, Blood transfusion, Liver disease. 
INTRODUCTION: Hepatitis-C is a global disease. It has been estimated that the global prevalence of Hepatitis-C virus (HCV) infection is around 3.3\% with 200 million persons chronically infected with the virus and 3 to 4 million persons newly infected added every year[1] Where as in 2011, it was found that the global prevalence of HCV was found to be $2.35 \%$ affecting 160 million chronically infected individuals ${ }^{[2]}$. Hepatitis-C, in combination with hepatitis-B, now accounts for $75 \%$ of all cases of liver disease around the world.

HCV can lead to chronic liver disease causing cirrhosis, hepatocellular carcinoma and end stage liver disease among $5-20 \%$ of infected persons.[2] India is estimated to have 168,000-1.1 million IDUs (intravenous drug users) with HCV antibody prevalence ranging from 5 to 93\%; among HIV+ IDUs it is as high as 100percent.[3,4,5,6,7,8]

India's blood banking system has serious short comings. Professional blood donation continues to flourish despite stringent law. Improperly sterilized needles are reused for drawing blood or pushing drugs. It has been well documented that the dialysis patients have a higher rate of HCV infection. The rate of seroconversion among haemodialysis patients with no other risk factors has been reported 1.38-1.9\%/year. ${ }^{[9,10]}$

The present study aims at finding out the seroprevelance of Hepatitis-C virus in high risk individuals as well as healthy blood donors.

MATERIALS AND METHODS: A prospective case control study was carried out in the department of Microbiology, S.C.B. medical college and hospital, Cuttack in collaboration with departments like Gastroenterology, Nephrology, Drug de-addiction cum rehabilitation centre and ICTC (Integrated counseling and testing centre) for a period of 15 months from march 2005 to June 2006.

The study group comprise of 350 subjects which included 150 healthy voluntary blood donors as control groups and 200 subjects taken from different high risk population like IV drug abuser (50), patient on long term haemodialysis (40), with chronic liver disease (50), HIV positive cases (30), Health care workers exposed to HCV positive blood by accidental needle stick injuries or sharp exposure (30). The informed consent was obtained from the patients before collecting the sample.

$3.5 \mathrm{ml}$ of venous blood was collected from each patient using disposable needle and syringe in a sterile dry and labelled vial and was allowed to clot. The blood samples were centrifuged at $1000 \mathrm{rpm}$ for 15 minutes and the separated serum was preserved at $4-8^{\circ} \mathrm{C}$ for one week.

Micro well ELISA was done by using third generation HCV microlisa (J. Mitra and Co. ltd.) for the detection of antibodies to hepatitis C viral antigens such as Core, NS3, NS4 and NS5 in human serum. All the samples and reagents were brought to room temperature $\left(20-30^{\circ} \mathrm{C}\right)$ before use.

\section{STATISTICAL ANALYSIS USED: Percentage}

RESULTS: Out of 150 healthy voluntary blood donors screened, only $01(0.66 \%)$ male in the age group of 31-40 was found to be positive for antiHCV antibody. (Table-1)

Amongst 200 high risk individuals screened, 24 (12\%) were found to be positive for antiHCV antibody. Amongst the positive cases for HCV antibody, the seropositivity in IV drug abusers, patients with chronic liver disease, HIV positive individuals and haemodialysis cases were found to be 58.33\% (14/24),16.66\%(4/24),16.66\% (4/24) and 8.33\%(2/24) respectively. Health care personnel were negative for antiHCV antibody $0 \%$ (Table 2). Seropositivity, among 
IV drug users, was seen more in males in the age group of 21-30 (50\%) and 31-40 years (35.7\%). Only one female in the age group of 31-40 was positive for antiHCV antibody (Table 3). Co-infection of HCV with HIV was found to be $13.33 \%$. Out of which $10 \%$ had the history of parenteral drug abuse and the rest with multiple sexual contact. (Table-4)

DISCUSSION: Transfusion of blood and blood products has been a leading cause of transmission of HCV, however due to improved screening, transmission through transfusion decreased in developed countries. The incidence of transfusion related hepatitis $\mathrm{C}$ infection dropped from $4.9 \%$ to $1.9 \%$ in Japan, $3.84 \%$ to $0.57 \%$ in USA.[11] However, the highest incidence (54\%) of transfusion related HCV infection was found in a study of 147 Chilean patients with chronic hepatitis- C. ${ }^{[12]}$ In New Delhi and Kolkata, in India, the prevalence of antiHCV antibody in healthy blood donors was $1.85 \%$ and $2 \%$ respectively. [13],[14] In a previous study in early 2002 at cuttack, the prevalence of antiHCV antibody in healthy voluntary blood donor was $2.12 \% .{ }^{[15]}$ In contrary to this result, in the present study the seroreactivity for HCV was $0.66 \%(1 / 150)$ only. The low prevalence in the present study may be due to mandatory screening for HCV infection introduced in late 2002.In 2010,a study at Kolkata, revealed still lower prevalence $0.35 \%$ for HCV antibody.[16]

Out of the total 200 high risk group 12\% (24/200) were ELISA positive for antiHCV Ab. Parenteral drug abusers showed a higher infection rate of $58.33 \%(14 / 24)$ followed by patients with chronic liver disease $16.66 \%$ (4/24) and 16.66\% (4/24) in HIV co-infected cases. Transmission of Hepatitis $\mathrm{C}$ virus has been strongly associated with intravenous and percutaneous drug and needle use. Reported cases of Hepatitis $\mathrm{C}$ from intravenous drug use are on the rise in different parts of the globe. Study at Baltimore in Maryland and Antwerp \& Limburg in Belgium reported a prevalence of HCV in IV drug abuser is $30.3 \%, 71 \%$ and $46 \%$ respectively.[17],[18] A recent study in London England, on 428 IV drug abusers, revealed 44\% seroreactivity for HCV antibody compared to $4 \%$ for HIV.[19] Seroprevelance of HCV among IV drug abusers was an alarming $92 \%$ and $71.2 \%$ at Manipur and Mizoram of India, respectively .[20][21] In a recent study at Chennai, HCV antibody prevalence was 5.5\% (63/1158) among Intravenous drug users(10/15) [22]. The importance of intravenous drug use cannot be overemphasized. The prevalence of HCV among people who acquired HIV through intravenous drug use reaches $90 \%$. [23] Co-infection of the two viruses can make treatment more difficult. In our study co-infection of HCV with HIV is found to be $13.33 \%(4 / 30)$, out of which $10.3 \%(3 / 40)$ had history of parenteral drug abuse and 3.3\% (1/30) with history of multiple contact.

The seroprevelance of hepatitis $C$ in chronic liver disease in India has ranged from $3-31 \%$. .24 IThe studies at Chandigarh and Tamilnadu reported seroreactivity for antiHCV antibody to be $48 \%$ and $5.6 \%$ respectively.[25],[26] In the present study, the seroreactivity for antiHCV antibody in patients with chronic liver disease was found to be $8 \%(4 / 50)$. Equal number of males and females (two each) had antiHCV antibody. Both the females were diagnosed as hepatocellular carcinoma. A significantly high prevalence of co-infection (HCV and HBV) rate of $24.7 \%$ was also reported from Punjab.[27]

Patients on haemodialysis are at an increased risk for acquiring hepatitis $\mathrm{C}$ infection, as a result of cross contamination from the dialysis circuits. In the 90's at many places of the world the prevalence rate of HCV infection in dialysis patients was 10-50\%.[28], [29], [30]Previously in Europe the prevalence rate was as high as $20-30 \%$. By 2000, the rate of seroconversion among haemodialysis patients with no other risk factors has been reported 1.38-1.9\% /year.[31],[32] In India there is much variation in the prevalence rate of $\mathrm{HCV}$, in dialysis 
patients varying from $4.3 \%$ at Delhi to as high as $13.23 \%$ and $46 \%$ at Hyderabad.[33],[34],[35] Stringent blood testing and isolation of dialysis machines have helped in reduction of hepatitis C transmission. In present study, 5\% (2/40) patients with chronic renal failure on long term haemodialysis were found to be positive for anti HCV antibody.

Health care workers are at a higher risk for acquiring hepatitis infection as they come in contact with potentially infected subjects. Prevalence of hepatitis $\mathrm{C}$ among health workers range from $0-4 \%$ in this population. ${ }^{[36],[37]}$ In our study none out of 30 health workers, found to be seroreactive for antiHCV antibody.

Hepatitis $\mathrm{C}$ is an emerging infection whose long term implications will be felt in the decades to come. In the absence of vaccine, primary prevention of hepatitis $\mathrm{C}$ should target reduction of the transmission of the virus.

Prevention should target those at risk of acquiring virus and therefore should involve providing education, risk reduction counseling, substance abuse treatment and HCV screening following the centre of disease control (CDC) guidelines such as screening drug abusers, receiver of blood and its products(clotting factor concentrates) and organs, screening persons with long term dialysis, children of HCV positive women, health care workers and persons with evidence of chronic liver disease. [27]

ACKNOWLEDGEMENT: I express my heartfelt thanks to Mr. Dilip Barik, for his technical support during this study. I also like to thank with deep sense of appreciation to Mr. Prasanta Kumar Pradhan for his computer assistance in preparing this manuscript.

\section{REFERENCES:}

1. Shepard CW Finelli L and Alter MJ. Global epidemiology of hepatitis C virus infection. Lancet Infect Dis. 2005; 5: 558-567

2. Lavanchy D.Evolving epidemiology of hepatitisC virus.Clinical Microbiology And Infection,Feb 2011;17:107-115

3. Seelff LB Buskell-Bales Z, Wright EC, Deeraco SJ, Alter HJ, Iber FL et al. Long term mortality after transfusion associated non-A, non-B hepatitis. The National Heart, Lung and Blood Institute study Group. New Engl J Med 1992; 327:1906-11.

4. Mathers BM, Deglenhardt L, Philips B, Wiessing L, Hickman M, Strathdee SA et al. Global epidemiology of injecting drug use and HIV among people who injects drugs: a systemic review. Lancet 2008; 372:1733-45.

5. Aceijas C, Friedman SR, Cooper HL, Wiessing L, Stinson GV, Hickman M. Estimates of injecting drug users at the national and local level in developing and transitional countries and gender and age distribution. Sex Transm Infect 2006; 82 (suppl 3):10-7

6. Kumar M.S, Mudaliar S, Thyagarajan SP, Kumar S, Selvanayagam A, Daniels D. Rapid assessment and response to injecting drug use in Madras, south India. IThe International J of Drug Policy2000; 11: 83-98.

7. Mahanta J, Medhi G K, Paranjape R S, Roy N, Kohli A, Akoi Tam B S, et al. Injecting and sexual risk behaviours, sexually transmitted infections and HIV prevalence in injecting drug users in three states of India. AIDS 2008; 22 (suppl 5)559-68.

8. Jain M, Chakravarti A, Verma V, Bhala P. Seroprevalence of hepatitis viruses in patients infected with human immuno deficiency virus. Indian J pathol Microbiol 2009;52:17-19 
9. Solowon SS, Hawcroft CS, Narashima P, Subbaraman R, Srikrishnan AK, Cecelia A J et al. Comorbidities among HIV injected injection drug users in Chennai, India: A cause for concern. J Acqir Immune Lefic Syndr 2008; 49:327-32.

10. Halfon P, Khiri H, Feryn JM, Sayada C, Chanas M and Ouzan D. Prospective virological follow up of hepatitis $C$ infection in a haemodialysis unit. J viral Hepat 1998; 5: 115-21.

11. Fabrizi F, Martin P, Dixit V, Brezina M, Russell J, Conrad A, schimid P, Gerosa S, Gitnick G. Detection of de novo hepatitis $\mathrm{C}$ virus infection by polymerase chain in haemodialysis patients. Am J Nephrol 1999; 19: 383-388.

12. Theodore Sy, M. Mazen Jamal. Epidemiology of Hepatitis C virus (HCV) infection. Int. J. Med Sci 2006; 3: 41-46.

13. Soza A, Arrese M, Gonzalez R, Alvarez M, Perez RM, Cortes P, Patillo A, Riquelme A. Clinical and epidemiological features of 147 chilean patients with chronic hepatitis $\mathrm{C}$. Ann Hepatol. 2004; 3(4):146-151.

14. Panigrahi AK, Panda S.K, Dixit RK, Rao KV, Acharya S.K, Dasarathy S, Nanu A . Magnitude of hepatitis $C$ virus infection in India. Prevalence in healthy donors, acute and chronic liver diseases. J Med Virol, 1997; 51:167-174.

15. Hazara S C, Chatterjee S, Das Gupta S, Choudhary V, Jana CK and Neogi DK. Changing scenario of transfusion related viral infection. J Assoc. Physicians India.2002; 50:879881.

16. Mishra S, Chayani N, Sarangi G, Mallick B, Pati SB. Serprevalence of antiHCV antibody in and around cuttack,Orissa.Indian J Med Microbiol.2002;20:40-1.

17. Das BK, Gayen BK, Aditya S, Chakrovorty SK, Datta PK, Joseph A. Seroprevalence of Hepatitis B, Hepatitis C, and human immunodeficiency virus among healthy voluntary first-time blood donors in Kolkata. Ann Trop Med Public Health.2011; 4:86-90.

18. Villano SA, Vlahov D, Nelson KE, Lyles CM, Cohn S, Thomas DL. Incidence and risk factors for hepatitis C among injection drug users in Baltimore, Maryland. J Clin Microbiol 1997; 35:3274-3277.

19. Mathei C, Robaeys G, Van Danne P, Buntire F, Verrando R. Prevalence of Hepatitis C in drug users in Flanders, determinants and geographic differences. Epidemiol. Infection 2005; 133: 127-136.

20. Judd A, Hickman M, Jones S, Mc Donald T, Parry JV, Stimson G.V, Hall AJ. Incidence of hepatitis $\mathrm{C}$ virus and HIV among new injecting drug users in London. Prospective cohort study. BMJ 2005; 330:24-5.

21. Chelleng PK, Borkakoty BJ, Chetia M, DasHK, Mahanta J. Risk of hepatitis C infection among injection drug users in Mizoram, India. Indian JMed Res2008;128:640-646

22. Saha MK, Chakraborty S, Panda S, Nayak TN, Manna B, Chaterjee A, Detels R and Bhatacharya S.K. Prevalence of HCV and HBV infection among HIV seropositive intravenous drug users and their non-injecting wives in Manipur, India. Indian J Med. Res, 2000; 111:37-39.

23. Shruti H. Meheta, Sawantha L. Vogt, Alur K Srikrishnan, Conjee varam K vasudevan, Kallilapuri G Murgavel, Shanmugam Saravanam, Santhanam Anand, M Suresh kumar, Stuart C Ray, David D. Celentano, Sumiti solowan and Sunil S Solomon. Epidemiology of hepatitis $C$ virus infection and liver disease among Injection drug users (IDUs) in Chennai, India. Indian J Med Res, Dec 2010; 132:706-714. 
24. Agrawal N, Naik S, Kini D, Somani S K , Sing H, Agrawal R. HCV as a cause of liver cirrhosis, frequency and genotype distribution. Indian Gastro-enterol 2001; 20 (suppl.2):A83.

25. Singh V, Katyal R, Kochar R K, Bhasin D K, Agrawal R P. Study of hepatitis B and C viral markers in patients of chronic liver disease. Indian J Med microbial 2004; 22: 269-70.

26. Sood ASS, Midha V and Jyoti D. High seroprevalence of hepatitis C virus and dual infection (hepatitis B and C virus) in non alcoholic liver disease in north India; J Assoc. Physicians India.1999;47:405-407.

27. Anbazhagan GK, Krishnamoorty S, Thiyagrajan T. Seroprevalence of HCV and its coinfection with HBV and HIV among liver disease patients of south Tamil Nadu. World J Hepatol2010;2(1):42-48.

28. Niu M T, Coleman PJ, Alter MJ. Multicentre study of hepatitis C virus infection in chronic haemodialysis patients and staff. Am J kidney 1993; 22:568-573.

29. Medin C, Allander T, Roll M, Jacqlison SH, Grillner L. Seroconversion to hepatitis C virus in dialysis patients, a retrospective and prospective study. Nephron 1993; 65: 40-45.

30. Theodore Sy, M .Mazen Jawal. Epidemiology of Hepatitis C virus (HCV) Infection. Int. J. Med. Sci. 2006; 3:41-45.

31. Halfon P, Khiri H, Feryn JM, Sayada C, Chanas M, Ouzan D. Prospective virological follow up of hepatitis C infection in a haemodialysis unit. J viral Hepat 1998; 5: 115-121

32. Fabrizi F, Martin P, Dixit V, Brezina M, Russell J, Conrad A, schimid P, Gerosa S, Gitnick G. Detection of de novo hepatitis $C$ virus infection by polymerase chain in hemodialysis patients. Am J Nephrol 1999; 19: 383-388.

33. Agarwal S.K, Dash S C and Irshad M. Hepatitis C virus infection during haemodialysis in India. J. Assoc. Physicians India 1999;47:1139-1143

34. Chandra M, Khaja M N, Hussain M M, Poduri(1), Farees N, Habeel M A, Krishnan S, Rawa Reddy G V and Habibullah C M. Prevalence of hepatitis B and hepatitis C viral infections in Indian patients with chronic renal failure. Inter virology 2004; 47: 374-376.

35. Reddy A K, Murthi K V and Lakshmi V. Prevalence of HCV infection in patients on hemodialysis: Survey by antibody and core antigen detection; Indian J Med. Microbiol, 2005;23: 106-110

36. Arankalle VAJJ Favorv M O, Chaudhuri A, Fields H A, Banerjee K. Contribution of HEV and $\mathrm{HCV}$ in causing fulminant non- $\mathrm{A}$, non-B hepatitis in western India. J viral Hepatol.1995; 2: 189-193.

37. Ganju S A and Goel A. Prevalence of HBV and HCV infection among health care workers (HCWs). J. Commun. Dis.2000; 32: 228-30.

Table-1: Seroprevelance of antiHCV Ab in control group

\begin{tabular}{|c|c|c|c|}
\hline CONTROL GROUP & NUMBER & ELISA +VE & PERCENTAGE (\%) \\
\hline HEALTHY BLOOD DONOR & 150 & 1 & $0.66 \%$ \\
\hline
\end{tabular}


Table-2: Seroprevelance of antiHCV Ab in different high risk group

\begin{tabular}{|l|c|c|c|}
\hline \multicolumn{1}{|c|}{ HIGH RISK GROUP } & NUMBER & ELISA+VE & $\begin{array}{c}\text { \% IN RESPECT OF TOTAL } \\
\text { ELISA POSITIVE }\end{array}$ \\
\hline IV DRUG ABUSER & 50 & 14 & $58.33 \%$ \\
\hline HAEMODIALYSIS & 40 & 2 & $8.33 \%$ \\
\hline CHRONIC LIVER DISEASE & 50 & 4 & $16.66 \%$ \\
\hline HEALTH CARE PERSONNEL & 30 & 0 & $0 \%$ \\
\hline HIV+VE CASES & 30 & 4 & $16.66 \%$ \\
\hline TOTAL & 200 & 24 & $100 \%$ \\
\hline
\end{tabular}

Table-3: ELISA positive cases of IV drug abusers in relation to age and sex

\begin{tabular}{|l|c|c|c|c|c|c|}
\hline \multicolumn{1}{|c|}{ AGE } & MALE & FEMALE & $\begin{array}{c}\text { TOTAL } \\
\text { M+F }\end{array}$ & $\begin{array}{c}\text { MALE } \\
\text { POSITIVE }\end{array}$ & $\begin{array}{c}\text { FEMALE } \\
\text { POSITIVE }\end{array}$ & $\begin{array}{c}\text { TOTAL } \\
\text { M+F } \\
\text { POSITIVE }\end{array}$ \\
\hline $10-20$ & 6 & 0 & 6 & $1(7.14 \%)$ & 0 & 1 \\
\hline $21-30$ & 20 & 3 & 23 & $7(50 \%)$ & $1(7.14 \%)$ & 8 \\
\hline $31-40$ & 17 & 0 & 17 & $5(35.7 \%)$ & 0 & 5 \\
\hline $41-50$ & 4 & 0 & 4 & 0 & 0 & 0 \\
\hline TOTAL & 47 & 3 & 50 & $13(92.85 \%)$ & $1(7.14 \%)$ & 14 \\
\hline
\end{tabular}

Table-4: Coinfection of HIV and HCV

\begin{tabular}{|l|c|c|}
\hline HIV+VE & NO. & ANTI HCV Ab+VE \\
\hline WITH H/O PARENTERAL DRUG ABUSE & 15 & $3(10 \%)$ \\
\hline WITH H/O MULTIPLE SEXUAL CONTACT & 15 & $1(3.33 \%)$ \\
\hline TOTAL & 30 & $4(13.33 \%)$ \\
\hline
\end{tabular}

